\title{
Frestun læknispjónustu meðal Íslendinga: Umfang og skýringar
}

Rúnar Vilhjálmsson, félagsfræððingur ${ }^{1}$

\section{ÁGRIP}

Tilgangur: Jafnt aðgengi að heilbrigðispjónustu er meginmarkmið i félagslegum heilbrigðiskerfum eins og pví íslenska. Fyrri innlendar rannsóknir benda til pess að talsverður munur sé á aðgengi einstaklinga og hópa að heilbrigðispjónustunni. Markmið rannsóknarinnar var að kortleggja frestun læknispjónustu i ólikum samfélagshópum fullorðinna Íslendinga og meta vægi einstakra áhrifapátta.

Efniviður og aðferðir: Rannsóknin byggði á landskönnuninni Heilbrigði og aðstæður Íslendinga I. Spurningalistar voru póstsendir til pjóðskrárúrtaks Íslendinga á aldrinum 18-75 ára. 1532 manns svöruðu könnuninni og heimtur voru 60\%.

Niðurstöður: Alls höfðu 22\% fullorðinna Íslendinga frestað eða fellt niður læknispjónustu á sex mánaða tímabili. Frestunarhlutföll voru misjöfn eftir hópum. Peir sem voru ungir að árum í fullri vinnu, áttu við fjárhagserfiðleika að etja, höfðu há heimilisútgjöld vegna heilbrigðispjónustu, áttu erfitt með að komast frá daglegum verkefnum, voru óánægðir með síðustu læknisheimsókn, eða glímdu við langvinna sjúkdóma og kvilla, frestuðu oftar en aðrir ferð til læknis. Ályktun: Nokkuð algengt er að Íslendingar fresti eða felli niður læknispjónustu sem peir telja pörf fyrir. Jafnframt er verulegur munur á tíðni frestunar milli fólks og hópa. Niðurstöðurnar eru umhugsunarefni i ljósi pess meginmarkmiðs heilbrigðiskerfisins að allir landsmenn hafi jafnan aðgang að heilbrigðispjónustu. Mikilvægt er að heilbrigðisyfirvöld leiti leiða til að jafna aðgengi einstaklinga og hópa að læknispjónustu og vinni gegn frestun eða niðurfellingu hennar.

Fyrirspurnir: Rúnar Vilhjálmsson runarv@hi.is

Barst: 31. mars 2011, - sampykk til birtingar: 14 . september 2011.

Höfundur tiltekur engin hagsmunatengsl. Rannsóknina styrktu Rannsóknasjóđur Rannís og Rannsóknasjóður Háskóla Íslands.

\section{Inngangur}

Samkvæmt lögum um heilbrigðispjónustu nr. 40/2007 skulu allir landsmenn eiga kost á fullkomnustu heilbrigðispjónustu sem tök eru á að veita á hverjum tíma. Í íslenskri heilbrigðisáætlun til ársins 2010 kemur fram að mikilvægt sé að aðgengi að heilbrigðispjónustu sé auðvelt og sem jafnast fyrir alla landsmenn (markmið 2). Bein útgjöld einstaklinga megi aldrei vera pað mikil að pau komi í veg fyrir að fólk leiti sér nauðsynlegrar heilbrigðispjónustu (markmið 17). ${ }^{1,2}$

Segja má að jafnt aðgengi að heilbrigðispjónustu sé meginmarkmið í félagslegum heilbrigðiskerfum eins og pví íslenska. ${ }^{1,3}$ Petta markmið gerir ráð fyrir að notkun einstaklinga á heilbrigðispjónustu ráðist af pörf peirra fyrir pjónustuna. Ef aðgengi að heilbrigðispjónustu er jafnt, ætti ólík notkun einstaklinga á pjónustunni einungis að stafa af pví að einn hefur meiri pörf fyrir pjónustuna en annar. Ef ólík notkun pjónustunnar stafar af ólíkum möguleikum einstaklinga til að verða sér úti um pjónustuna, eða af pví að sumir hafa ríkari tilhneigingu en aðrir til að leita sér aðstoðar vegna tiltekinna einkenna eða aðstæðna, má ætla að um sé að ræða ójafnt aðgengi og ójafnræði í útdeilingu pjónustunnar., 5

\section{Félags- og lýdfræðilegir pættir}

Fjölmargar erlendar rannsóknir á ólíku aðgengi einstaklinga og hópa að heilbrigðis- og læknispjónustu liggja fyrir. Pannig virðist eldra fólk frekar leita til heilbrigðispjónustunnar en miðaldra og yngra fólk pegar upp koma ýmsir kvillar og sjúkdómar.6, 7 Petta getur stafað af pví að eldra fólkið hafi meiri tilhneigingu til pjónustunotkunar eða betri tækifæri til pess en aðrir aldurshópar. Jafnframt virðast konur nota heilbrigðispjónustu frekar en karlar, ekki síst við skammvinn eða bráð einkenni. ${ }^{6}$ Raunar benda rannsóknir til pess að kynferði hafi sjálfstæð áhrif á pjónustunotkun pótt tekið sé tillit til sjúkdóma og kvilla. ${ }^{8-10}$ Fáar rannsóknir hafa athugað aðgengi að heilbrigðispjónustu eftir hjúskapar- eða foreldrastöðu, en pó eru vísbendingar um að aðgengi giftra og ekkjufólks sé betra en einhleypra og fráskilinna, ${ }^{8,}$ 9 en óljósara er hvort foreldrar leikskólabarna noti heilbrigðispjónustuna frekar eða síður en peir sem ekki hafa fyrir börnum að sjá.5, 11 Ólíkar niðurstöður hafa komið fram um aðgengi að heilbrigðispjónustu eftir búsetu, par sem sumar rannsóknir leiða í ljós búsetumun ${ }^{12}$ en aðrar ekki. ${ }^{13}$ Pá benda rannsóknir til að útivinnandi fólk noti heilbrigðispjónustuna síður vegna veikinda en peir sem ekki vinna úti ${ }^{7}$, sem kann að stafa af pví að útivinnandi fólk komist síður frá verkefnum til að sækja sér heilbrigðispjónustu. Rannsakendur virðast almennt sammála um að lágtekjufólk noti heilbrigðispjónustuna í ríkari mæli en fólk með hærri tekjur. Pegar tekið hefur verið tillit til parfar fyrir heilbrigðispjónustuna minnkar munur á pjónustunotkun tekjuhópanna ${ }^{6,14}$ og pegar kemur að einkarekinni pjónustu og sérfræðipjónustu virðist lágtekjufólk nota heilbrigðispjónustuna minna en pörf 
Tafla I. Frestun/niðurfelling læknisheimsóknar eftir skýringarbreytum.

\begin{tabular}{|c|c|c|c|}
\hline & \multicolumn{3}{|c|}{ Frestun/niðurfelling heimsóknar } \\
\hline & \% (fjöldi) & $\begin{array}{l}\text { Phi/ } \\
\text { Cramér's V }\end{array}$ & $p^{a}$ \\
\hline \multicolumn{4}{|l|}{ Aldur } \\
\hline $18-24$ & $27,4(57 / 208)$ & & \\
\hline $25-34$ & $29,9(81 / 271)$ & & \\
\hline $35-44$ & $22,6(70 / 310)$ & & \\
\hline $45-54$ & $20,7(60 / 290)$ & 0,15 & 0,00 \\
\hline $55-64$ & $16,9(40 / 237)$ & & \\
\hline $65+$ & $9,3(16 / 172)$ & & \\
\hline \multicolumn{4}{|l|}{ Kynferði } \\
\hline Karl & $20,6(155 / 752)$ & & \\
\hline Kona & $22,7(168 / 740)$ & 0,03 & 0,33 \\
\hline \multicolumn{4}{|l|}{ Hjúskaparstaða } \\
\hline Gift(ur)/Sambúð & $19,5(208 / 1069)$ & & \\
\hline Einhleyp(ur) & $27,6(79 / 286)$ & & \\
\hline Fráskilin(n) & $27,8(25 / 90)$ & 0,09 & 0,01 \\
\hline Ekkja/Ekkill & $20,0(6 / 30)$ & & \\
\hline \multicolumn{4}{|c|}{ Foreldri barns yngra en 6 ára } \\
\hline Já & $25,8(100 / 388)$ & & \\
\hline $\mathrm{Nei}$ & $20,2(220 / 1088)$ & 0,06 & 0,02 \\
\hline \multicolumn{4}{|l|}{ Atvinnustaða } \\
\hline Utan vinnumarkaðar & $17,3(31 / 179)$ & & \\
\hline Hlutastarf & $17,5(65 / 371)$ & 0,08 & 0,02 \\
\hline Fullt starf ( $\geq 40$ stundir) & 23,9 (199/834) & & \\
\hline \multicolumn{4}{|l|}{ Atvinnulaus } \\
\hline Já & $21,5(17 / 79)$ & & \\
\hline $\mathrm{Nei}$ & $21,8(283 / 1296)$ & $-0,00$ & 0,95 \\
\hline \multicolumn{4}{|l|}{ Í námi } \\
\hline Já & $26,4(73 / 277)$ & & \\
\hline Nei & $20,5(229 / 1116)$ & 0,06 & 0,04 \\
\hline \multicolumn{4}{|l|}{ Búseta } \\
\hline Reykjavíkursvæði & $20,5(195 / 952)$ & & \\
\hline Landsbyggð & $23,7(128 / 540)$ & 0,04 & 0,15 \\
\hline \multicolumn{4}{|l|}{ Menntun } \\
\hline Grunnskólapróf & $22,7(107 / 472)$ & & \\
\hline Framhaldsskólapróf & $22,0(131 / 596)$ & 0,03 & 0,60 \\
\hline Háskólapróf & $19,9(77 / 387)$ & & \\
\hline \multicolumn{4}{|c|}{ Fjölskyldutekjur á síðasta ári } \\
\hline 0-2,4 miljónir & $27,1(55 / 203)$ & & \\
\hline 2,5-6,4 miljónir & $23,2(148 / 638)$ & 0,08 & 0,03 \\
\hline 6,5 miljónir eða meira & $18,2(80 / 440)$ & & \\
\hline \multicolumn{4}{|l|}{ Fjárhagserfið̋leikar } \\
\hline Engir & $17,5(196 / 1117)$ & & \\
\hline Nokkrir (1-3) & $28,0(71 / 254)$ & 0,24 & 0,00 \\
\hline Miklir (4+) & $58,8(50 / 85)$ & & \\
\hline
\end{tabular}

krefur. ${ }^{15-17}$ Ólíkt pví sem gildir um tekjur virðist menntun hafa lítil áhrif á aðgengi að heilbrigðispjónustu ef marka má erlendar rannsóknir. ${ }^{9,16}$ Pó eru vísbendingar um að fólk með minni menntun noti sérfræðipjónustu síður en peir sem hafa meiri menntun og að fyrirbyggjandi notkun heilbrigðisbjónustu sé fátíðari hjá fólki með minni menntun. ${ }^{16}$

\section{Hlutverk og skyldur}

Misjafnt er hversu sveigjanlegar starfsskyldur og dagleg verkefni fólks eru. Peir sem gegna ósveigjanlegum hlutverkum og eiga erfitt með að komast frá daglegum skyldum í vinnu eða á heimili gætu frestað heimsókn til heilbrigðisstarfsmanns pótt peir teldu pörf á heimsókninni. Bandarískar rannsóknir benda til að útivinnandi fólk og fólk með miklar fjárhagslegar skuldbindingar leiti síður en aðrir til heilbrigðispjónustunnar með langvinn veikindi sín. ${ }^{7}$ petta kann meðal annars að stafa af erfiðleikum við að komast frá daglegum verkefnum, en pó skortir vitneskju um pað.

\section{Heilsufar og örorka}

Heilsufar getur haft áhrif á aðgengi fólks að heilbrigðispjónustu. Peir sem búa við langvinna sjúkdóma, andlega eða líkamlega fötlun og örorku purfa oft að leita til fleiri en eins aðila í heilbrigðiskerfinu yfir lengri tíma. ${ }^{18}$ Slíkar aðstæður geta leitt til aukinnar frestunar eða niðurfellingar heimsókna. ${ }^{19}$ Pá er mögulegt að erfiðleikar langveikra og fatlaðra við að ferðast um og komast til og frá pjónustuaðilum hamli notkun heilbrigðispjónustu.

\section{Heilbrigðispjónustan}

Loks má nefna að aðgengi og frestun heilbrigðispjónustu ræðst að verulegu leyti af pví hvernig pjónustan er skipulögð og hvernig greitt er fyrir hana. Einstaklingar sem hafa tiltekinn lækni sem peir pekkja með nafni og geta snúið sér til nota heilbrigðispjónustuna frekar en hinir sem ekki hafa tengsl við lækni. ${ }^{13}$, 16 Peir sem búa í næsta nágrenni pjónustustaðar leita frekar til læknis en hinir sem purfa að fara um lengri veg. ${ }^{21}$ Einnig benda niðurstöður til að peir sem hafa áður kostað miklu til heilbrigðispjónustu fresti frekar en aðrir ferð til læknis. ${ }^{19,}{ }^{21}$

Innlendar rannsóknir benda til pess að útgjöld sjúklinga í heilbrigðispjónustunni á Íslandi hafi aukist undanfarin ár og að aðgengi að pjónustu sé misjafnt milli hópa. Í rannsóknum sem byggðust á heilbrigðiskönnun meðal fullorðinna Íslendinga frá 1997, kom í ljós að yngra fólk, fráskildir, foreldrar ungra barna og lágtekjufólk frestaði frekar læknispjónustu en aðrir. Pá kom í ljós að peir sem bjuggu við fjárhagserfiðleika, höfðu haft mikil útgjöld vegna heilbrigðispjónustu, áttu erfitt með að komast frá daglegum verkefnum, purftu að fara um lengri veg til læknis, höfðu ekki afsláttarkort eða bjuggu við langvinna sjúkdóma, frestuðu frekar en aðrir ferð til læknis. 5, 19, 20

Enn er sitthvað á huldu um pjónustufrestun hérlendis og hinar ýmsu ástæður hennar. Pá er ekki vitað hvort breytingar hafi orðið á frestun læknispjónustu eða helstu áhrifapáttum frestunar. Pessari rannsókn er ætlað að kortleggja frestun læknispjónustu í einstökum samfélagshópum fullorðinna Íslendinga og meta vægi mögulegra áhrifapátta. Athugað er hvort frestun læknispjónustu er með misjöfnum hætti eftir félags- og lýðfræðilegum páttum og hvort fjárhagserfiðleikar og ósveigjanleg hlutverk (erfiðleikar að komast frá daglegum verkefnum) kunni 
að hamla notkun læknispjónustunnar. Pá er athugað hvort neikvæð viðhorf og neikvæð reynsla af læknispjónustunni tengist frestun pjónustunnar. Eins er athugað hvort tengsl við lækni og pjónustustað, vegalengd og ferðatími á pjónustustaðinn, afsláttarkort og fyrri útgjöld vegna heilbrigðispjónustu tengist frestun hennar. Jafnframt er athugað hvort peir sem eiga við langvinna sjúkdóma og örorku að glíma fresti frekar ferð til læknis en aðrir. Að lokum er lagt mat á hvaða pættir skipta mestu pegar leitað er skýringa á frestun læknispjónustunnar.

\section{Efniviður og aðferðir}

Rannsóknin byggir á landskönnuninni Heilbrigði og aðstæður Íslendinga I sem fram fór haustið 2006. ${ }^{22,}{ }^{23}$ Íslenskir ríkisborgarar á aldrinum 18-75 ára og búsettir á Íslandi voru valdir með slembiaðferð úr pjóðskrá. Langstærstur hluti spurninga í listanum var forprófaður og prófaður í fyrri heilbrigðiskönnunum meðal Íslendinga., ${ }^{24}$ Framkvæmd póstkönnunarinnar fylgdi svokallaðri heildaraðferð (Total Design Method, TDM) sem náð hefur betri heimtum í póstkönnunum en eldri aðferðir. ${ }^{25}$ Í samræmi við TDMaðferðina var sendur út spurningalisti allt að prisvar sinnum á sjö vikna tímabili. Pá var einnig sent út ítrekunar- og pakkarkort viku eftir fyrstu útsendingu spurningalista. Í framhaldi af síðustu útsendingu spurningalista samkvæmt TDM-aðferðinni var að auki hringt í alla sem ekki höfðu skilað lista eða neitað að taka pátt. Alls svöruðu 1532 manns könnuninni og svarhlutfall var 60,03\%. Lýðfræðileg samsetning svarendahóps og pýðis var mjög ápekk, nema hvað svörun var heldur hærri meðal kvenna en karla og hærri meðal íbúa á landsbyggðinni en íbúa á höfuðborgarsvæðinu. Niðurstöður voru pví vegnar eftir búsetu og kynferði svo pær gæfu réttari mynd af pýðinu. ${ }^{22}$ Persónuvernd og vísindasiðanefnd veittu leyfi fyrir framkvæmd landskönnunarinnar.

Frestun læknispjónustu var metin með eftirfarandi spurningu: „Purftir pú að fara til læknis einhvern tíma á síðastliðnum sex mánuðum, en hættir við pað eða frestaðir pví (já, nei)?“ Könnuð voru tengsl frestunar læknispjónustu við eftirfarandi breytur: Aldur, kynferði, hjúskaparstöðu (gift(ur)/í sambúð, í föstu sambandi/einhleyp(ur), fráskilin(n), ekkja/ekkill), foreldrastöðu (barn yngra en sex ára, ekki barn yngra en sex ára), atvinnustöðu (ekki í starfi, hlutastarf, fullt starf), atvinnuleysi (atvinnulaus nú, ekki atvinnulaus nú), námsstöðu (í skóla, ekki í skóla), búsetu (höfuðborgarsvæði, landsbyggð), menntun (grunnskóla-, gagnfræða- eða landspróf, sérskóla- eða stúdentspróf, háskólastigspróf), heimilistekjur (árstekjur í krónum), fjárhagserfiðleika (átta atriða kvarði, svo sem að eiga í vandræðum með að borga af reikningum, hafa ekki ráð á matvörum, fatnaði, eða húsbúnaði sem pörf var fyrir; Chronbach's alpha=0,84), ósveigjanleg hlutverk (fimm prepa kvarði frá „alls ekki erfitt“ til „nánast útilokað“ að komast frá daglegum verkefnum ef leita pyrfti læknis), ánægju með síðustu heimsókn til læknis (mjög eða frekar ánægður, hlutlaus, mjög eða frekar óángður), afstöðu til notkunar fólks á læknispjónustu (frekar eða mjög mótfallin/n, hlutlaus, frekar eða mjög fylgjandi), hvort viðkomandi hafi heimilislækni, eða fari venjulega á tiltekinn stað pegar leitað er til læknis, vegalengd (í kílómetrum) og ferðatíma (í mínútum) til pess læknis eða heilsugæslustöðvar sem viðkomandi notar oftast, heildarútgjöld fjölskyldunnar til heilbrigðismála á ársgrundvelli
Tafla I - Framhald

\begin{tabular}{|c|c|c|c|}
\hline & \multicolumn{3}{|c|}{ Frestun/niðurfelling heimsóknar } \\
\hline & \% (fjöldi) & $\begin{array}{l}\text { Phi/ } \\
\text { Cramér's V }\end{array}$ & $\mathrm{p}^{\mathrm{a}}$ \\
\hline \multicolumn{4}{|c|}{ Ósveigjanleg hlutverk (Að komast frá daglegum verkefnum) } \\
\hline Ekki erfitt & $16,7(172 / 1031)$ & & \\
\hline Dálítið erfitt & $31,7(71 / 224)$ & 0,19 & 0,00 \\
\hline Nokkuð eða mjög erfitt & $36,3(78 / 215)$ & & \\
\hline \multicolumn{4}{|c|}{ Ánægja með síðustu læknisheimsókn } \\
\hline Óánægð(ur) & $45,6(52 / 114)$ & & \\
\hline Hlutlaus & $31,8(68 / 214)$ & 0,21 & 0,00 \\
\hline Ánægð(ur) & $17,4(186 / 1071)$ & & \\
\hline \multicolumn{4}{|c|}{ Afstaða til notkunar læknispjónustu } \\
\hline Neikvæð & $10,0(1 / 10)$ & & \\
\hline Hlutlaus & $21,3(32 / 150)$ & 0,02 & 0,66 \\
\hline Jákvæð & $21,9(283 / 1294)$ & & \\
\hline \multicolumn{4}{|l|}{ Hefur heimilislækni } \\
\hline Já & $21,4(231 / 1081)$ & & \\
\hline Nei & $23,1(90 / 389)$ & $-0,02$ & 0,47 \\
\hline \multicolumn{4}{|c|}{ Fer á tiltekinn stað pegar leita parf til læknis } \\
\hline Já & $21,2(250 / 1178)$ & & \\
\hline Nei & $24,7(71 / 288)$ & $-0,03$ & 0,21 \\
\hline \multicolumn{4}{|l|}{ Vegalengd til læknis } \\
\hline Stutt ( $\leq 20$ kílómetrar) & $21,6(294 / 1358)$ & & \\
\hline Löng (>20 kílómetrar) & $20,2(18 / 89)$ & $-0,01$ & 0,75 \\
\hline \multicolumn{4}{|l|}{ Ferðatími til læknis } \\
\hline Stuttur ( $\leq 20$ mínútur) & $21,8(292 / 1337)$ & & \\
\hline Langur (>20 mínútur) & $20,3(25 / 123)$ & $-0,01$ & 0,70 \\
\hline \multicolumn{4}{|c|}{ Heildarútgjöld fjölskyldu til heilbrigðismála (î púsundum króna á ári) } \\
\hline $0-50,0$ & $15,7(50 / 319)$ & & \\
\hline $50,1-93,7$ & $23,7(75 / 317)$ & & \\
\hline $93,8-142,0$ & $19,8(64 / 323)$ & 0,10 & 0,01 \\
\hline $142,1+$ & $26,4(83 / 314)$ & & \\
\hline \multicolumn{4}{|c|}{ Heildarútgjöld fjölskyldu til heilbrigðismála (\% af fjölskyldutekjum) } \\
\hline $0-1,04$ & $13,8(39 / 283)$ & & \\
\hline $1,05-1,83$ & $22,7(64 / 282)$ & & \\
\hline $1,84-3,01$ & $18,6(52 / 279)$ & 0,17 & 0,00 \\
\hline $3,02+$ & $32,5(92 / 283)$ & & \\
\hline \multicolumn{4}{|c|}{ Afsláttarkort vegna komugjalda } \\
\hline Já & $22,3(48 / 215)$ & & \\
\hline Nei & $21,7(274 / 1263)$ & 0,01 & 0,84 \\
\hline \multicolumn{4}{|c|}{ Langvinnir sjúkdómar eða kvillar } \\
\hline Enginn & $16,8(117 / 697)$ & & \\
\hline Einn & $22,4(71 / 317)$ & & \\
\hline Tveir & $23,1(43 / 186)$ & 0,14 & 0,00 \\
\hline Prír eða fleiri & $31,7(92 / 290)$ & & \\
\hline \multicolumn{4}{|l|}{ Örorka (75\%) } \\
\hline Já & $33,8(24 / 71)$ & & \\
\hline Nei & $21,2(279 / 1318)$ & 0,07 & 0,01 \\
\hline
\end{tabular}


(î púsundum króna), heilbrigðisútgjöld fjölskyldu sem hlutfall af fjölskyldutekjum, hvort viðkomandi hafi afsláttarkort vegna komugjalda, 75\% örorku, og langvinna sjúkdóma/kvilla (hvort svarendur hafi haft einhvern af 48 langvinnum sjúkdómum og kvillum síðastliðna 12 mánuði, og hvort læknir hafi staðfest pað). ${ }^{23}$

Í tölfræðilegri úrvinnslu voru tengsl frestunar læknisheimsóknar við aðrar breytur fyrst athuguð með krosstöflum (crosstabulation), marktæki sambanda ákvörðuð með kí-kvaðrat prófi, og fí-fylgnistuðull reiknaður fyrir minni (2x2) krosstöflur, en Cramer's V-fylgnistuðull pegar krosstöflurnar voru stærri. Til að leggja mat á mikilvægustu skýringabreytur frestunar voru hrein (nettó) tengsl marktækra óháðra breyta við frestun læknispjónustu metin með marghliða lógaritmalínulegri aðhvarfsgreiningu (multivariate logistic regression). Óháðar breytur voru valdar 1 aðhvarfsjöfnuna ein af annarri með framvirku prepavali (stepwise selection) par til allar marktækar óháðar breytur voru komnar í jöfnuna. Pess má geta að í krosstöflugreiningunni voru allar jafnbilabreytur flokkaðar (sjá lýsingu á breytum að framan), en óflokkaðar í aðhvarfsgreiningunni.

\section{Niðurstöður}

Alls höfðu 22\% svarenda frestað læknisheimsókn sem peir töldu pörf fyrir síðastliðna sex mánuði. Tafla I sýnir tengsl einstakra breyta við frestun læknispjónustu. Elsta fólkið frestaði sjaldnast læknisheimsókn en yngra fólkið oftast, einhleypir og fráskildir frestuðu frekar heimsókn en aðrar hjúskaparstéttir, foreldrar leikskólabarna, fólk í fullu starfi, stúdentar og lágtekjufólk frestaði sömuleiðis frekar en aðrir læknisheimsókn. Pá sýnir tafla I að peir sem bjuggu við fjárhagserfiðleika, áttu erfitt með að komast frá daglegum verkefnum, voru óánægðir með pá

Tafla II. Lógaritmalínuleg aðhvarfsgreining á páttum tengdum frestun/niðurfellingu læknispjónustu (framvirkt prepaval) $(N=941)^{a}$.

\begin{tabular}{|c|c|c|c|c|}
\hline & $B(S E B)$ & OR & $(95 \% \mathrm{Cl})$ & $\mathrm{p}$ \\
\hline Aldur (ár) & $\begin{array}{l}-0,031 \\
(0,007)\end{array}$ & 0,969 & $\begin{array}{l}(0,956 \\
0,983)\end{array}$ & 0,000 \\
\hline $\begin{array}{l}\text { Atvinnupátttaka } \\
\text { (klukkustundir á viku) }\end{array}$ & $\begin{array}{c}0,012 \\
(0.005)\end{array}$ & 1,012 & $\begin{array}{c}(1,003 \\
1,021)\end{array}$ & 0,012 \\
\hline $\begin{array}{l}\text { Fjárhagserfiðleikar } \\
\text { (kvarði frá } 0 \text { til 8) }\end{array}$ & $\begin{array}{c}0,237 \\
(0,053)\end{array}$ & 1,268 & $\begin{array}{c}(1,142 \\
1,408)\end{array}$ & 0,000 \\
\hline $\begin{array}{l}\text { Heildarútgjöld fjölskyldu vegna } \\
\text { heilbrigðismála } \\
\text { (púsundir króna á ári) }\end{array}$ & $\begin{array}{c}0,004 \\
(0,001)\end{array}$ & 1,004 & $\begin{array}{l}(1,001 \\
1,006)\end{array}$ & 0,012 \\
\hline $\begin{array}{l}\text { Ósveigjanleg hlutverk } \\
\text { (kvarði frá } 0 \text { til 4) }\end{array}$ & $\begin{array}{c}0,327 \\
(0,085)\end{array}$ & 1,386 & $\begin{array}{r}(1,174 \\
1,637)\end{array}$ & 0,000 \\
\hline $\begin{array}{l}\text { Ánægja með síðustu } \\
\text { læknisheimsókn } \\
\text { (kvarði frá -2 til 2) }\end{array}$ & $\begin{array}{l}-0,518 \\
(0,086)\end{array}$ & 0,596 & $\begin{array}{c}(0,503 \\
0,705)\end{array}$ & 0,000 \\
\hline $\begin{array}{l}\text { Langvinnir sjúkdómar/ } \\
\text { kvillar (fjöldi) }\end{array}$ & $\begin{array}{c}0,201 \\
(0,051)\end{array}$ & 1,223 & $\begin{array}{c}(1,106 \\
1,351)\end{array}$ & 0,000 \\
\hline Fasti & $-1,037$ & & & \\
\hline Likelihood Ratio $\chi^{2}(\mathrm{df})$ & $\begin{array}{c}161,064 \\
(7)\end{array}$ & & & \\
\hline Negelkerke $\mathrm{R}^{2}$ & 0,243 & & & \\
\hline
\end{tabular}

a Tala í sviga gefur til kynna fjölda einstaklinga með gild svör á öllum breytum aðhvarfsgreiningarinnar. Öðrum einstaklingum var sleppt (listwise deletion). læknispjónustu sem peir höfðu áður fengið, höfðu haft mikinn kostnað af heilbrigðispjónustunni, voru langveikir, eða öryrkjar, frestuðu frekar læknispjónustu en aðrir. Ekki reyndist marktækur munur á frestun með tilliti til kynferðis, atvinnuleysis, búsetu, menntunar, viðhorfa til læknispjónustu, afsláttarkorts, ferðatíma eða vegalengdar til læknis, eða pess að hafa heimilislækni eða fara á tiltekin stað pegar leita skal læknis.

Tafla II sýnir niðurstöður aðhvarfsgreiningar á peim skýringapáttum sem höfðu marktæk hrein (nettó) tengsl við frestun læknispjónustu að teknu tilliti til annarra skýringapátta. Samkvæmt niðurstöðunum minnka líkur á frestun með hækkandi aldri, en með aukinni atvinnupátttöku aukast líkurnar. Fjárhagserfiðleikar, bein útgjöld fjölskyldu vegna heilbrigðispjónustu, ósveigjanleg hlutverk (erfiðleikar við að komast frá daglegum verkefnum) og óánægja með síðustu læknisheimsókn auka einnig líkur á frestun læknispjónustu. Pá sýnir tafla II að eftir pví sem langvinnir sjúkdómar og kvillar eru fleiri aukast líkur á frestun læknispjónustu. Negelkerke $R^{2}$ er 0,243 og gefur til kynna hve stóran hluta af breytileika í frestun læknispjónustu má rekja til skýringarbreytanna (á skalanum frá 0-1).

\section{Umræða}

Samkvæmt rannsókninni frestuðu 22\% fullorðinna Íslendinga læknispjónustu á sex mánaða tímabili. Petta er svipað hlutfall og níu árum fyrr ${ }^{5,19}$ pegar $24 \%$ fullorðinna Íslendinga sögðust hafa frestað læknispjónustu sem peir purftu á að halda (munurinn á hlutföllunum er ekki marktækur). Lágt frestunarhlutfall meðal eldra fólks er í samræmi við fyrri erlendar og innlendar niðurstöður. ${ }^{6,7,19}$ Раð hefur meðal annars verið skýrt með pví að eldra fólk hafi almennt góða tryggingavernd í heilbrigðiskerfinu (lægri komugjöld og rétt til afsláttarkorts við lægri útgjaldamörk), hafi gjarnan lausan tíma til að sinna heilsu sinni og veikindum, og hafi oftast tengsl við ákveðna heilbrigðisstarfsmenn og pekkingu á heilbrigðiskerfinu vegna fyrri pjónustunotkunar, en allir pessir pættir vinna gegn frestun læknispjónustu., ${ }^{5,19}$ Hátt frestunarhlutfall meðal yngra fólks er að mestu í samræmi við fyrri innlendar rannsóknir ${ }^{5,19}$ sem er sérstakt umhugsunarefni. Rétt er að hafa í huga að yngra fólkið hefur almennt fremur lágar tekjur, en parf engu að síður að greiða sömu komugjöld í heilbrigðiskerfinu og tekjuhærra fólk. Pá er yngra fólkið landfræðilega hreyfanlegt (ekki síst námsmenn) og hefur takmarkaða reynslu af heilbrigðiskerfinu, en hvort tveggja getur hamlað notkun heilbrigðispjónustunnar. Í pessu sambandi væri ástæða til að huga betur að tryggingavernd og aðgengi pessa hóps og aukinni nærpjónustu, til dæmis í formi almennrar skólaheilsugæslu fyrir námsmenn á framhalds- og háskólastigi. Tengsl atvinnupátttöku við frestun læknispjónustu hafa verið skýrð með pví að einstaklingar í fullu starfi séu oft uppteknir og gefi sér síður tíma til að leita sér lækninga en peir sem eru í hlutastarfi eða utan vinnumarkaðar." ${ }^{19}$ Pessi skýring tengist peirri niðurstöðu rannsóknarinnar að fólk sem á erfitt með að komast frá daglegum verkefnum frestar frekar heimsókn til læknis. Heilbrigðiskerfið og pá einkum heilsugæslan gæti komið til móts við pennan hóp einstaklinga með aukinni vaktpjónustu á kvöldin og um helgar, enda veikist fólk ekki endilega á dagvinnutíma heilsugæslustöðvanna. Pá er pað umhugsunarvert að takmörkuð vaktpjónusta heilsugæslunnar krefst margfalt hærri komugjalda en 
pjónusta sem í boði er á dagvinnutíma. Líklegt er að pað fæli ýmsa frá heilsugæslunni sem eru uppteknir á daginn við vinnu eða nám en kæmust frekar til læknis á kvöldin og um helgar. Há uppsöfnuð útgjöld vegna heilbrigðismála og fjárhagserfiðleikar einstaklinga auka einnig til muna frestun læknispjónustu. Pessar niðurstöður benda til að aðgerðir stjórnvalda til að draga úr kostnaðar- og fjárhagsáhrifum í heilbrigðispjónustunni hafi ekki tekist sem skyldi. Pá gefur rannsóknin til kynna að neikvæð reynsla af heilbrigðiskerfinu fæli fólk frá frekari pjónustunotkun. Pessar niðurstöður eru í samræmi við tilgátu um kerfispröskuld (systems barrier), sem sett var fram fyrir allmörgum árum af bandaríska félagsfræðingnum Diane Dutton, en samkvæmt henni hafa einstaklingar og hópar misjafna reynslu af heilbrigðiskerfinu sem skýrir af hverju sumir leita síður til heilbrigðispjónustunnar en aðrir. ${ }^{26}$ Loks er að nefna pær niðurstöður rannsóknarinnar að langveikir einstaklingar frestuðu frekar en aðrir ferð til læknis og að líkur á frestun jukust eftir pví sem langvinnir kvillar einstaklingsins voru fleiri. Bent hefur verið á að langveikir purfi oft að leita á fleiri staði vegna heilsuvandamála sinna og jafnvel oft á hvern stað, ${ }^{18}$ sem getur aukið líkur á frestun eða niðurfellingu læknisheimsóknar. ${ }^{19}$ Auk pess eru uppsöfnuð útgjöld vegna heilbrigðispjónustu oft há hjá pessum einstaklingum. Ein helsta gagnrýni á vestræn heilbrigðiskerfi er að vegna vaxandi sérhæfingar og aðgreiningar stofnana og starfsmanna sé pjónustan oft brotakennd og ósamfelld og pví ráðist pað að miklu leyti af sjúklingnum sjálfum hvort pjónustan sem hann parf á að halda sé óslitin og heildstæð. Petta á ekki síst við um langveika. Leiðir til að bæta aðgengi og draga úr frestun eða niðurfellingu pjónustu felast pví meðal annars í að styrkja tengsl og samstarf pjónustuaðila, færa pjónustuna nær sjúklingnum og veita honum aukna ráðgjöf og aðstoð við útvegun nauðsynlegrar pjónustu.

Nokkrar skýringarbreytur höfðu marktæk tengsl við frestun læknispjónustu einar og sér (tafla I), en reyndust ekki marktækar í marghliða aðhvarfsgreiningu pegar tekið var tillit áhrifa annarra breyta (tafla II). Í pví sambandi má sérstaklega nefna að pó munur væri á frestun eftir fjölskyldutekjum, tengdust fjölskyldutekjur ekki frestun með beinum hætti í aðhvarfsgreiningu, einkum vegna áhrifa fjárhagserfiðleika og langvinnra veikinda, en báðir pættirnir tengdust tekjum. Pá frestuðu öryrkjar mun oftar læknisheimsókn en aðrir, en örorka tengdist ekki frestun með beinum hætti í aðhvarfsgreiningu, einkum vegna áhrifa aldurs, langvinnra veikinda, fjárhagserfiðleika og útgjalda vegna heilbrigðismála, en allir pessir pættir tengdust örorku.
Styrkleikar rannsóknarinnar felast meðal annars í pví að úrtak var á landsvísu, heimtur voru viðunandi og raunar betri en almennt gerist í póstkönnunum meðal almennings, ${ }^{27}$ auk pess sem fjölmargar skýringarbreytur voru teknar til athugunar. Meðal takmarkana má nefna að rannsóknin byggði á pversniðskönnun og sambönd breyta voru athuguð á einum tímapunkti. Pví gefur rannsóknin ekki óyggjandi niðurstöður um orsakatengsl milli breyta. Pá er rétt að nefna að ekki var lagt klínískt mat á ástand og einkenni peirra sem frestuðu læknispjónustu og pví ekki unnt greina frestunartilvik eftir alvarleika peirra. Pörf er á rannsóknum með langtímasniði er meta áhrif skýringarbreyta á frestun læknispjónustu fram í tímann. Pá er ástæða til að greina alvarleika frestunartilvika og leggja mat á hvort frestun kunni að vera misalvarleg eða -afdrifarík eftir pví hvaða samfélagshópur á í hlut.

\section{Ályktanir}

Talsvert er um að Íslendingar fresti eða felli niður læknispjónustu, jafnvel pótt peir telji pörf fyrir pjónustuna. Jafnframt er verulegur munur á frestunartíðni milli einstaklinga og hópa. Frestun var fátíðust hjá eldra fólki, en algengust hjá langveikum og öryrkjum, peim sem glímdu við fjárhagserfiðleika, höfðu kostað miklu til heilbrigðismála, áttu erfitt með að komast frá daglegum verkefnum eða voru óánægðir með síðustu læknisheimsókn. Niðurstöðurnar eru verulegt umhugsunarefni í ljósi pess meginmarkmiðs íslenska heilbrigðiskerfisins að allir landsmenn hafi sem jafnastan aðgang að heilbrigðispjónustu. Mikilvægt er að heilbrigðisyfirvöld leiti leiða til að jafna aðgengi einstaklinga og hópa að heilbrigðispjónustunni og vinni gegn frestun eða niðurfellingu hennar, svo sem með aukinni tryggingavernd, einkum í viðkvæmum hópum, eflingu heilsugæslunnar og vaktpjónustu innan hennar, og annarri nærpjónustu, svo sem heimatengdri pjónustu og skólaheilsugæslu.

\section{Pakkir}

Heilbrigðiskönnunin Heilbrigði og aðstæður Íslendinga hlaut styrk frá Rannsóknasjóði Rannís og Rannsóknasjóði Háskóla Íslands. 


\section{Heimildir}

1. Heilbrigðis- og tryggingamálaráðuneytið. Heilbrigðisáætlun til ársins 2010: Langtímamarkmið í heilbrigðismálum. Heilbrigðis- og tryggingamálaráðuneytið, Reykjavík 2001.

2. Vilhjálmsson R. Íslenska heilbrigðiskerfið á krossgötum. Í: Jóhannesson G., ritstj. Rannsóknir í félagsvísindum VIII. Félagsvísindastofnun, Reykjavík 2007: 197-206.

3. Cockerham WC. Medical sociology, 11th ed.: PrenticeHall, Upper Saddle River, NJ 2010.

4. Aday LA, Fleming GV, Andersen R. Access to medical care in the US: Who has it, who doesn't? Pluribus Press, Chicago, IL 1984.

5. Vilhjálmsson R, Ólafsson Ó, Sigurðsson JÁ, Herbertsson TР (2001). Aðgangur að heilbrigðispjónustu á Íslandi. Landlæknisembættið, Reykjavík 2001. www.landlaeknir. is/Uploads/FileGallery/Utgafa/utg_adgangur01.pdf mars 2011.

6. Adams PF, Benson V. Current estimates from the National Health Interview Survey, 1991. National Center for Health Statistics, Hyattsville, MD 1992.

7. Marcus AC, Siegel JM. Sex differences in the use of physician services: A preliminary test of the fixed role hypothesis. J Health Soc Behav 1982; 23: 186-97.

8. Benzeval M, Judge K. Access to health care in England: continuing inequalities in the distribution of GPs. J Public Health Med 1996; 18: 33-40.

9. Eyles J, Birch S, Newbold KB. Delivering the goods? Access to family physician services in Canada: a comparison of 1985 and 1991. J Health Soc Behav 1995; 36 : 322-32.
10. Sharp K, Ross CE, Cockerham WC. Symptoms, beliefs, and the use of physician services among the disadvantaged. J Health Soc Behav 1983; 24: 255-63.

11. Evandrou M, Falkingham J, Le Grand J, Winter D. Equity in health and social care. J Soc Policy 1992; 21: 489-523.

12. Aday LA, Andersen RM. Equity of access to medical care: a conceptual and empirical overview. Í: President's Commission for the Study of Ethical Problems in Medicine and Biomedical and Behavioral Research: securing access to health care. Vol. 3. Government Printing Office, Washington, DC 1983: 19-54.

13. Berk ML, Schur CL, Cantor JC. Ability to obtain health care: recent estimates from the Robert Wood Johnson Foundation National Access to Care survey. Health Aff 1995; 14: 139-46.

14. Gerdtham UG, Sundberg G. Equity in the delivery of health care in Sweden. Scand J Public Health 1998; 26: 259-64

15. van Doorslaer E, Koolman X, Puffer F. Equity in the use of physician visits in OECD countries: has equal treatment for equal need been achieved? Í: Measuring up: improving health systems performance in OECD countries. OECD, Paris, France 2002: 225-48.

16. Dunlop S, Coyte PC, McIssac W. Socioeconomic status and the utilisation of physicians' services: results from the Canadian National Population Health Survey. Soc Sci Med 2000; 51; 123-33.

17. Schofield D. Ancillary and specialist health services: the relationship between income, user rates and equity of access. Aust J Soc Issues 1999; 1: 79-96.
18. Strauss AL, Corbin J, Fagerhaugh S, et al. Chronic illness and the quality of life. Mosby, St. Louis, MO 1984

19. Vilhjálmsson R. Failure to seek needed medical care: results from a national health survey of Icelanders. Soc Sci Med 2005; 61: 1320-30.

20. Vilhjálmsson $\mathrm{R}$, Jörundsdóttir $\mathrm{E}$, Sigurðardóttir $\mathrm{H}$, Jóhannsdóttir bB. pættir tengdir aðgengi að læknispjónustu á Íslandi. Í: Sveinsdóttir H, Nyysti A, ritstj. Framtíðarsýn innan heilsugæsluhjúkrunar. Rannsóknastofnun í hjúkrunarfræði og Háskólaútgáfan, Reykjavík 2001: 70-94.

21. Nemet GF, Bailey AJ. Distance and health care utilization among the rural elderly. Soc Sci Med 2000; 50: 1197-208.

22. Vilhjálmsson R. Landskönnunin Heilbrigði og aðstæður Íslendinga - Aðferð og framkvæmd. Hjúkrunarfræðideild Háskóla Íslands, Reykjavík 2007.

23. Vilhjálmsson R. Bein útgjöld íslenskra heimila vegna heilbrigðismála. Læknablaðið 2009; 95: 661-8.

24. Vilhjálmsson R, Kristjánsdóttir G, Sveinbjarnardóttir E. Factors associated with suicide ideation in adults. Soc Psychiatry Psychiatr Epidemiol 1998; 33: 97-103.

25. Dillman DA. The design and administration of mail surveys. Annu Rev Sociol 1991; 17: 225-49.

26. Dutton DB. Social class, health and illness. Í: Aiken LH, Mechanic D, ritstj. Applications of social science to clinical medicine and health policy. Rutgers University Press, New Brunswick, NJ 1986.

27. Baruch $Y$, Holtom BC. Survey response rate levels and trends in organizational research. J Hum Relations 2008; 61: 1139-60.

\section{ENGLISH SUMMARY}

\section{Postponement and cancellation of physician visits among Icelanders: Extent and explanations}

\section{Vilhjálmsson $\mathrm{R}$}

Objective: Equal access to health care is a central goal in socialized health systems like the one in Iceland. Previous research in Iceland indicates considerable individual and group differences in access to health care. The study maps the distribution of postponement and cancellation of physician care among Icelandic adults and considers a number of potential explanations.

Material and methods: The data come from a national postal health survey of Icelandic adults, age 18-75, who were randomly drawn from the National Register. 1532 individuals responded to the survey yielding a 60\% response rate.

Results: $22 \%$ of the respondents had postponed or cancelled a physician visit they thought they needed in the past 6 months. The study found considerable variations in postponement rates. Postponement was positively related to younger age, full employment, financial difficulties, high out-ofpocket health care costs, inflexible daily schedules (fixed roles), dissatisfaction with last physician visit, and the number of chronic medical conditions experienced.

Conclusions: Postponement or cancellation of medical care is fairly common among lcelandic adults, although considerable individual and group differences in postponement are observed. The results raise concerns, as equal access to care is a central goal of the Icelandic health care system. It is incumbent upon health authorities to pursue effective ways to equalize access to medical care and prevent postponement and cancellation of needed services.

Key words: cancellation of medical care, access to health care, health services utilization, group differences.

Correspondence: Rúnar Vilhjálmsson, runarv@hi.is 